\title{
Analysis of Embankment Supported by Rigid Inclusions Using Plaxis 3D
}

\author{
R.Alsirawan ${ }^{1, *}$ \\ ${ }^{1}$ Széchenyi István University, Department of Structural and Geotechnical \\ Engineering. \\ Egyetem tér 1, 9026 Győr, Hungary \\ *E-mail: Rashad.seirawan@gmail.com
}

Submitted: 07/05/2021; Accepted: 16/08/2021; Published online: 27/08/2021

Abstract: A rigid inclusion-supported embankment is used to overcome the problems of soft soils. This system is considered complex due to the various interactions between its elements, namely the embankment body, load transfer platform, geogrid layers, piles, and soft soils. The load transfer mechanism is based on the phenomenon of soil arching, the tension in the geogrid layers, support of the soft soils, and friction between piles and soft soil. In this paper, the first part highlights the behaviour of a rigid inclusion-supported embankment validated by field measurements, and the contribution of rigid inclusions technology to the reduction of settlement and creep settlement. In addition, the effect of geogrid in improving the load efficiency and reducing the settlements is presented. In the second part, a comparison is made between many analytical design methods and a three-dimensional finite element analysis method. The results show the inconsistencies between the analytical methods in calculating the load efficiency and the tension in the geogrid.

Keywords: rigid inclusion-supported embankment; load efficiency; $3 D$ finite element analysis

\section{Introduction}

Due to the unfavourable properties of soft soil, different technologies are used to support embankments on this type of soil to avoid excessive settlement and loss of 
bearing capacity. Many advantages motivate engineers to use rigid inclusions technology under embankments, buildings, and industrial facilities. Rigid inclusions fulfil the requirements of bearing capacity and settlements, rapid construction, and competitive cost.

The typical rigid inclusions system consists of rigid piles, with relatively small diameters, and load transfer platform LTP, located over the piles, which includes generally one or more layers of geosynthetics [1]. The vertical load is divided into three parts, Fig. 1:

1. Part A: this part is transferred directly to the rigid piles via the soil arch.

2. Part B: this part is transferred by geosynthetic layers to the rigid piles.

3. Part C: this part is transferred to the soft soil [2].

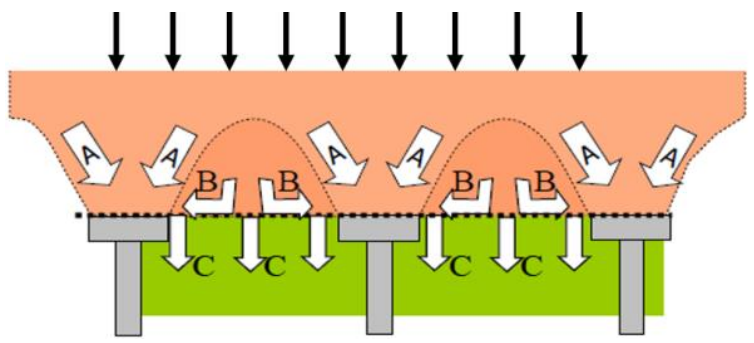

Figure. 1. Load transfer mechanism in embankment supported by rigid inclusions [2]

Han and Gabr [3] conducted a numerical study using the program Flac to investigate the interactions between $5 \mathrm{~s}$, soils, and geosynthetic reinforcement. The analysis showed that using the geosynthetic layers within the LTP and increasing the stiffness of the pile material leads to a reduction in the settlement at the embankment base. This study also found that the load efficiency (defined as the ratio of load acting on the pile head to the total vertical load resulting from the embankment weight and surcharge in a unit cell) increases as the elastic modulus of the pile increases and the height of the embankment increases. As for geosynthetic stress, this value increases as the stiffness of the geosynthetic, the elastic modulus of the pile, and the height of the embankment increase. A numerical study coupling the finite element method and the discrete element method described the load transfer mechanism. In this study, it was found that the load efficiency increases with high strength parameters of LTP soil, Chevalier et al. [4]. Abusharar et al. [5] proposed an analytical method of design. According to this method, the load efficiency increases with the height of the embankment at large cover ratios (defined as a ratio of the pile head (cap if any) to the LTP area), it also increases at high soil elastic modulus and small soft soil 
thicknesses. The geosynthetic tension increases linearly with the embankment height and decreases with the soil elastic modulus. Pham [6] presented a new analytical design method, the parametric study demonstrated that the load efficiency increases with the consolidation and low values of subgrade reaction modulus of subsoils, this study also showed that the tension decreases with the increase of the consolidation degree of subsoil, friction angle of LTP fill, and cover ratio. Fischer et al. [7] [8] found through an experimental tests that the performance and effectiveness of the geosynthetic reinforcement are affected by the ratio of the geosynthetic aperture size and the soil particle size, which in turn affects on the geosynthetic tension. Zhuang et al. [9] developed an analytical method and found that the tension increases linearly with the embankment height, pile spacing, and geogrid stiffness. van Eekelen et al. [10] performed a series of model tests in the laboratory, which showed that the use of a gravelly platform $\left(\varnothing=49^{\circ}\right)$ instead of a sandy platform $\left(\varnothing=40.88^{\circ}\right)$ increases the load efficiency. It increases also as a percentage whenever the uniform loads increase. The behaviour of geotextile and geogrid is similar in load transfer; therefore, the load efficiency and the tension are not affected by the type of reinforcement. These experiments led to the conclusion that the tension decrease in two cases, namely, when the friction angle of the LTP fill (gravelly platform) is high and when the stiffness of the reinforcement material is high. Girout et al. [11] performed thirty-three geotechnical centrifuge tests. The findings were, the presence of the reinforcement enhances the load efficiency, and the load efficiency depends on the stiffness and the positions of the reinforcement layers within the LTP.

This paper briefly describes the behaviour of rigid inclusions and the advantages of using this technology to reduce the settlements at the embankment surface in various cases. A comparison is also made between many analytical design methods and a numerical method using a validated model of an embankment supported by rigid inclusions.

\section{Background}

The design of rigid inclusions is considered complex due to the various interactions between the elements, which include the piles, geosynthetic layers, load transfer platform, and pile caps (if any) [1]. Over the past decades, many researchers have attempted to understand the interactions between the elements and the mechanism of load transfer. To achieve this end, many laboratory models, centrifuge tests, and full-scale tests have been conducted.

Various generations of methods are used to design rigid inclusions under embankments. All these methods are based on the theory of soil arching, which is based on a trap door experiment proposed by Terzaghi [12]. The first generation of methods includes Guido et al. [13], Hewlett and Randolph [14], Low et al. [15], 
Kempfert [16], Abusharar et al. [5], and others [17]. The differences between geosynthetic tension and load efficiency calculated by these methods are significant [17][18]. The differences can be attributed to the inadequacy of the tests or models and the inability to consider the effect of all parameters in this complex system. The finite element method is considered to be more comprehensive and can avoid the disadvantages of the previous methods.

BS8006 [19] and EBGEO [20] have proposed new design guidelines in both United Kingdom and Germany. Ellis and Aslam [21][22], van Eekelen et al. [10][23], Zhuang [9], Cui [24], Pham [6] worked on the analysis and design of this technology in the last decade. However, none of the proposed design methods provides realistic solutions in all case studies.

To calculate the geosynthetic tension and load efficiency, many design methods from different generations are chosen in this paper, as follows:

\subsection{Terzaghi's design method (1943)}

The theory of arching was used as the basis of this method, Russell and Pierpoint [25] expanded this method. The load efficiency is calculated as follows:

$$
E=1-\frac{S_{3 D}\left(s^{2}-a^{2}\right)}{s^{2}}
$$

where: $S_{3 D}$ is the stress reduction ratio and calculated according to equation (2), $a$ is the pile cap width $(\mathrm{m}), s$ is the pile spacing $(\mathrm{m})$.

$$
S_{3 D}=\frac{\left(\mathrm{s}^{2}-\mathrm{a}^{2}\right)}{4 H a K_{0} \tan \varnothing}\left(1-e^{\frac{-4 H a K_{0} \tan \emptyset}{\left(\mathrm{s}^{2}-\mathrm{a}^{2}\right)}}\right)
$$

where: $\mathrm{H}$ is the embankment height $(\mathrm{m}), K_{0}$ is the earth pressure coefficient at rest, $\emptyset$ is the friction angle of the embankment fill.

The tension in the geosynthetic layer is given by the following equation $(\mathrm{kN} / \mathrm{m})$ :

$$
T=\frac{S_{3 D} \gamma H\left(s^{2}-a^{2}\right)}{4 a} \sqrt{1+\frac{1}{6 \varepsilon}}
$$

where: $\gamma$ is the LTP soil unit weight $\left(\mathrm{kN} / \mathrm{m}^{3}\right), \varepsilon$ is the initial strain and equal to $5 \%$.

\subsection{Guido et al. design method (1987)}

The load efficiency is calculated by equation (1) and $S_{3 D}$ is calculated according to the following equation [13]: 


$$
S_{3 D}=\frac{s-a}{3 \sqrt{2} H}
$$

The tension in the geosynthetic layer can be calculated using equation (3)

\subsection{Hewlett and Randolph design method (1988)}

The load efficiency is calculated according to equation (1) and The tension in the geosynthetic layer can be calculated according to equation (3).

The stress reduction ratio $S_{3 D}$ is calculated using equations (5) and (6), the higher value is used in the design [14],

$$
\begin{gathered}
S_{3 D}=\left(1-\frac{a}{s}\right)^{2\left(K_{P}-1\right)}\left(1-\frac{2\left(K_{P}-1\right) s}{\sqrt{2} H\left(2 K_{P}-3\right)}\right)+\frac{2\left(K_{P}-1\right)(s-a)}{\sqrt{2} H\left(2 K_{P}-3\right)} \\
S_{3 D}=\frac{1}{\left(\frac{2 K_{P}}{1+K_{P}}\right)\left[\left(1-\frac{a}{s}\right)^{\left(1-K_{P}\right)}-\left(1-\frac{a}{s}\right)\left(1+\frac{a}{s} K_{P}\right)\right]+\left(1-\frac{a^{2}}{s^{2}}\right)}
\end{gathered}
$$

where: $K_{P}$ is the passive earth pressure coefficient and given by:

$$
K_{P}=\frac{1+\sin \emptyset}{1-\sin \emptyset}
$$

\subsection{Abusharar et al. design method (2009)}

Equation (7) is used to calculate the load efficiency [5]:

$$
E=1-\frac{\left(s^{2}-a^{2}\right) \sigma_{s}}{s^{2} \gamma H}
$$

where: $\sigma_{s}$ is the vertical stress acting on the geosynthetic layer $\left(\mathrm{kN} / \mathrm{m}^{2}\right)$.

The geosynthetic tension is given by:

$$
T=4 \beta^{2} J+0.25(s-a) \lambda\left(\sigma_{s} \tan \emptyset+\frac{t E_{c}}{D} \tan \emptyset_{c}\right)
$$

where: $\beta$ is the sag ratio and given as follows $\beta=t /(s-a), t$ is the maximum settlement of soft soil midway between rigid pile caps when geosynthetic is used $(\mathrm{m}), J$ is the geosynthetic tensile stiffness $(\mathrm{kN} / \mathrm{m}), \lambda$ is a factor that depends on the type of the geosynthetic and ranges between (0.7-0.9), $E_{c}, \emptyset_{c}, D$ are the elastic modulus $\left(\mathrm{kN} / \mathrm{m}^{2}\right)$, friction angle, and depth of the soft soil $(\mathrm{m})$. 


\subsection{BS8006 design method (2010)}

According to BS8006, two equations are proposed to calculate the load efficiency, equation (9) is used for partial arching, and equation (10) is used for full arching [19].

$$
\begin{gathered}
E=1-\frac{1}{s^{2}}\left[s^{2}-a^{2}\left(\frac{P_{c}}{\gamma H}\right)\right] \\
E=1-\frac{1.4(s-a)}{s^{2} H}\left[s^{2}-a^{2}\left(\frac{P_{c}}{\gamma H}\right)\right] \\
\frac{P_{c}}{\gamma H}=\left[\frac{C_{c} a}{H}\right]^{2}
\end{gathered}
$$

where: $P_{c}$ is the vertical stress acting on the pile caps $\left(\mathrm{kN} / \mathrm{m}^{2}\right), C_{c}$ is the arching coefficient, for end-bearing piles $\left(C_{c}=1.95 \mathrm{H} / a-0.18\right.$, for frictional piles $\left(C_{c}=\right.$ $1.5 \mathrm{H} / \mathrm{a}-0.07)$.

The geosynthetic tension is given by:

$$
T=0.5 W \frac{s-a}{a}\left(1+\frac{1}{6 \varepsilon}\right)^{0.5}
$$

For partial arching $[0.7(s-a) \leq H \leq 1.4(s-a)]$,

$$
W=\frac{\gamma H}{2(s-a)}\left[s^{2}-a^{2}\left(\frac{P_{c}}{\gamma H}\right)\right]
$$

For full arching $[H>1.4(s-a)]$,

$$
W=0,7 \gamma\left[s^{2}-a^{2}\left(\frac{P_{c}}{\gamma H}\right)\right]
$$

where: $W$ is the load acting on geosynthetic $(\mathrm{kN})$.

Equations (13), (14) are proposed by van Eekelen et al. [26] for use in the British Standard.

\subsection{Tuan A. Pham design method (2020)}

The load efficiency and geosynthetic tension are obtained from equations (15), (16) [6]:

$$
E=\frac{P_{c a}+P_{c m}}{(\gamma H+q) s^{2}}
$$




$$
T=\frac{8}{3}\left(\frac{8 y}{3(s-a)}\right)^{2} J+\left(\alpha_{P} \tan \emptyset_{p} \sigma_{s}^{a}+\alpha_{s} \tan \emptyset_{s} \sigma_{u p}+0.1 c_{s}\right)(s-a)
$$

where: $P_{c a}, P_{c m}$ are the loads on the pile (cap) via soil arch and through the geosynthetic layer $(\mathrm{kN}), y$ is the maximum deflection of the geosynthetic $(\mathrm{m})$, $\alpha_{P}, \alpha_{s}$ are the interaction coefficients between the soils and geosynthetic layer, $\emptyset_{p}, \emptyset_{s}$ are the friction angles of the soils at the top and bottom of the geosynthetic layer respectively, $\sigma_{s}^{a}$ is the vertical stress acting on the soft soil $(\mathrm{kPa}), \sigma_{u p}$ is the upward counter pressure from the soft soils $(\mathrm{kPa}), c_{S}$ is the total cohesion of the soils at the top and bottom of the geosynthetic $(\mathrm{kPa})$.

\section{Case study}

A full-scale model of an embankment supported by piles and two layers of uniaxial geogrids was performed in the Virvée swamp (France) within the frame of the new South Europe Atlantic high-speed line project [27]. The geometry information of the supported embankment and the geotechnical profile can be seen from the crosssection in Fig. 2. A working platform with a thickness of $1.0 \mathrm{~m}$ was constructed before the construction stages to support the movement of the equipment. The pile has a width of $0.274 \mathrm{~m}$ and a length of $12.7 \mathrm{~m}$. The precast concrete piles were driven in 60 working days, followed by the construction of the LTP with a thickness of 0.7 $\mathrm{m}$, this LTP includes two layers of geogrid at $(0.2-0.4) \mathrm{m}$ above the pile head. Finally, the embankment was constructed in two stages (represents the embankment body and traffic load), each $1.9 \mathrm{~m}$ thick. 


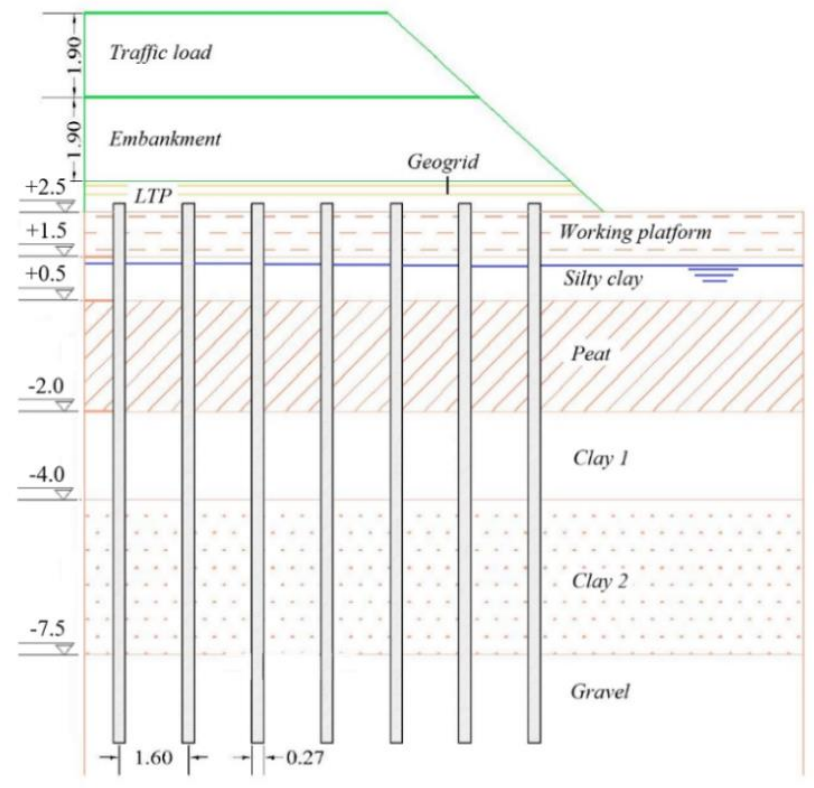

Figure 2. Cross-section of the rigid inclusion-supported embankment

\subsection{D Finite Element modelling}

Plaxis 3D CONNECT Edition V20 program is used to analyse the behaviour of the rigid inclusion-supported embankment, the dimensions of the model are $45 \mathrm{~m}$ in the $\mathrm{x}$-direction, $4.8 \mathrm{~m}$ in the $\mathrm{y}$-direction, as well as $25 \mathrm{~m}$ in the z-direction. Fig. 3 shows the typical FE mesh of this model.

For the validation of the model, six rings fixed along a magnet extensometer were used to measure the settlements in the soft soil layers during the construction stages and consolidation period, four earth pressure cells (EPCs) were fixed inside and over the LTP to measure the stresses in these points, three settlement sensors were installed to measure the vertical displacement of the pile head, and settlements at two representative measurement points inside the LTP [27]. 


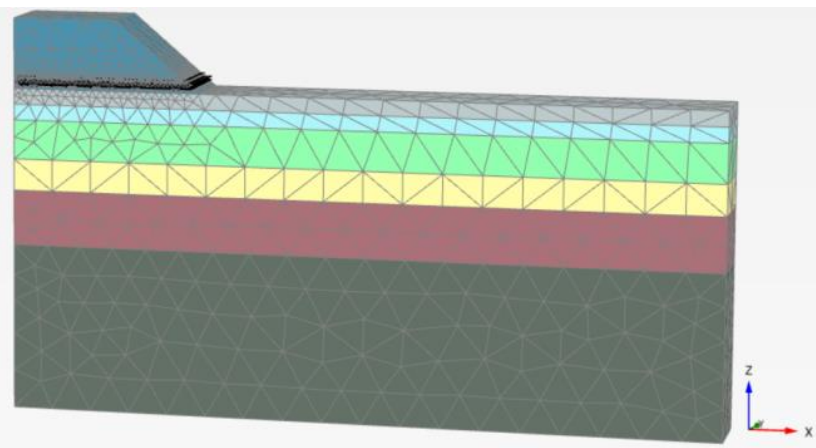

Figure 3. FE mesh of the supported embankment

The piles were modelled as embedded beam elements and the geogrid was modelled as elastoplastic material. The properties of the pile material and geogrid are listed in Table (1). Hardening soil model (HS) was used to simulate the behaviour of gravel, working platform, and embankment soils. Table (2) summarize the soil properties.

Table 1. Properties of pile material and geogrid

\begin{tabular}{|c|c|c|c|c|}
\hline & $\begin{array}{c}\text { Unit weight } \\
\gamma\left(k N / m^{3}\right)\end{array}$ & $\begin{array}{c}\text { Young modulus } \\
E(G P a)\end{array}$ & $\begin{array}{c}\text { Poisson } \\
\text { ratio }(v)\end{array}$ & $\begin{array}{c}\text { Stiffness } \\
(\mathrm{kN} / \mathrm{m})\end{array}$ \\
\hline Pile & 24 & 20 & 0.2 & - \\
\hline Geogrid & - & - & 0.2 & 13000 \\
\hline
\end{tabular}

The soft soil creep model (SSC) was used to simulate the behaviour of soft soils (silty clay, peat, and clay). The analyses for the gravel, working platform and embankment were modelled as drained condition and undrained condition for soft soils. The parameters of soft soils are tabulated in Table (3).

Table 2. Parameters of the embankment, working platform, and gravel soils

\begin{tabular}{|c|c|c|c|}
\hline & Embankment & Working platform & Gravel \\
\hline$\gamma_{\text {unsat }}\left(\mathrm{kN} / \mathrm{m}^{3}\right)$ & 21 & 21 & 19 \\
\hline$\gamma_{\text {sat }}\left(\mathrm{kN} / \mathrm{m}^{3}\right)$ & 21 & 21 & 20 \\
\hline$\varphi^{\circ}$ & 35 & 35 & 35 \\
\hline$\Psi^{\circ}$ & 5 & 5 & 5 \\
\hline $\mathrm{c}(\mathrm{kPa})$ & 5.0 & 5.0 & 10.0 \\
\hline $\mathrm{E}_{50}^{\mathrm{ref}}\left(\mathrm{kN} / \mathrm{m}^{2}\right)$ & 16000 & 12860 & 63000 \\
\hline $\mathrm{E}_{\text {oed }}^{\text {ref }}\left(\mathrm{kN} / \mathrm{m}^{2}\right)$ & 16000 & 12860 & 63000 \\
\hline $\mathrm{E}_{\text {ur }}^{\mathrm{ref}}\left(\mathrm{kN} / \mathrm{m}^{2}\right)$ & 48000 & 38580 & 189000 \\
\hline $\mathrm{m}$ & 0.5 & 0.5 & 0.5 \\
\hline
\end{tabular}




\begin{tabular}{|c|c|c|c|c|}
\hline $\mathrm{k}(\mathrm{m} /$ day $)$ & \multicolumn{5}{|c|}{0.864} & \multicolumn{2}{c|}{0.864} & 1.00 \\
\hline \multicolumn{5}{|c|}{ Table 3. Soft soil parameters } \\
\hline Layer & Silty clay & Peat & Clay 1 & Clay 2 \\
\hline$\gamma_{\text {unsat }}\left(\mathrm{kN} / \mathrm{m}^{3}\right)$ & 11.56 & 6.2 & 13.0 & 13.5 \\
\hline$\gamma_{\mathrm{sat}}\left(\mathrm{kN} / \mathrm{m}^{3}\right)$ & 15.0 & 10.6 & 14.0 & 14.5 \\
\hline$\varphi^{\circ}$ & 29 & 29 & 29 & 29 \\
\hline$\Psi^{\circ}$ & 0 & 0 & 0 & 0 \\
\hline $\mathrm{c}(\mathrm{kPa})$ & 4 & 4 & 4 & 4 \\
\hline$\lambda^{*}$ & 0.0928 & 0.2560 & 0.2016 & 0.1895 \\
\hline$\kappa^{*}$ & 0.0232 & 0.0845 & 0.0537 & 0.0475 \\
\hline$\mu^{*}$ & 0.0027 & 0.0010 & 0.0019 & 0.0018 \\
\hline $\mathrm{k}_{\mathrm{x}}, \mathrm{k}_{\mathrm{y}}(\mathrm{m} /$ day $)$ & $8.64 \mathrm{E}-4$ & $5.55 \mathrm{E}-4$ & $6.25 \mathrm{E}-4$ & $5.55 \mathrm{E}-4$ \\
\hline $\mathrm{k}_{\mathrm{z}}(\mathrm{m} / \mathrm{day})$ & $8.64 \mathrm{E}-4$ & $6.75 \mathrm{E}-4$ & $6.25 \mathrm{E}-4$ & $5.55 \mathrm{E}-4$ \\
\hline OCR & 8.40 & 7.85 & 3.23 & 1.45 \\
\hline & & & & \\
\hline
\end{tabular}

\section{Results and discussion}

The construction of the embankment over soft soil layers with undesirable characteristics yields excessive settlements and high excess pore pressure which is considered unsuitable for time-bound construction projects. In this section, the advantages of the rigid inclusions to overcome these difficulties are presented. Add to that, the behaviour of this system (stress distribution, soil-inclusion interactions), and the inconsistencies in some design methods are discussed also.

\subsection{Embankment surface settlements}

One of the objectives of using rigid inclusions technology is to reduce the settlement at the embankment surface, especially for embankments over soft soil layers, which are characterized by their high compressibility. Fig. 4 shows the maximum settlements at the embankment surface at different heights of the embankment and in different cases (unsupported embankment, embankment supported with piles, embankment supported with piles, and one layer of geogrid, and embankment supported with piles and two layers of geogrid). A comparison between the three improvement methods shows that the placement of one layer of geogrid reduces the settlements by $23 \%$ compared to embankments supported only with piles, while the placement of two layers reduces the settlements by $20 \%$. 


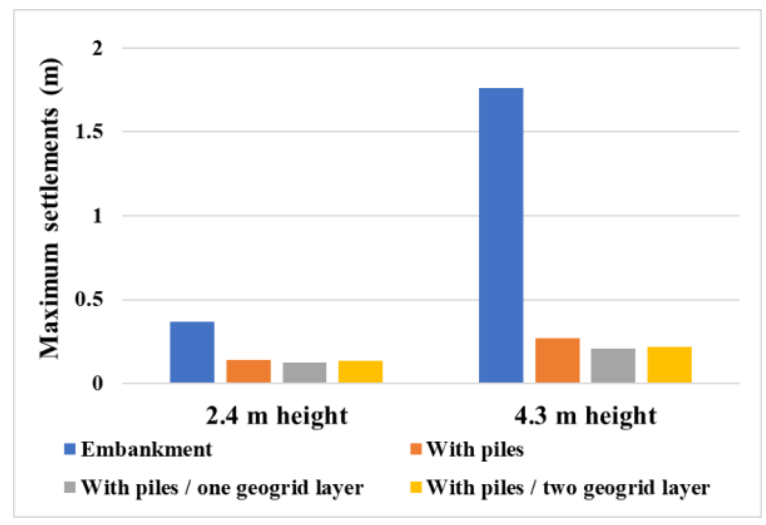

Figure 4. Maximum settlements at the embankment surface

Differential settlements at the embankment surface should be studied as maximum settlements. Rigid inclusions help to reduce differential settlements to acceptable levels, especially on high embankments. Differential settlements can be reduced also by adding one or two layers of geogrid within the LTP, making these settlements almost non-existent, as shown in Fig. 5.

\subsection{Excess pore pressure}

Fig. 6 shows the evolution of the excess pore pressure. Concerning the unsupported embankment, which is constructed in two stages to avoid soil collapse, the expected time of full consolidation is indefinite. When rigid inclusions technology is used, the dissipation of excess pore pressure is faster and the expected time of full consolidation is about 400 days, which is considered suitable for time-bound construction projects. 


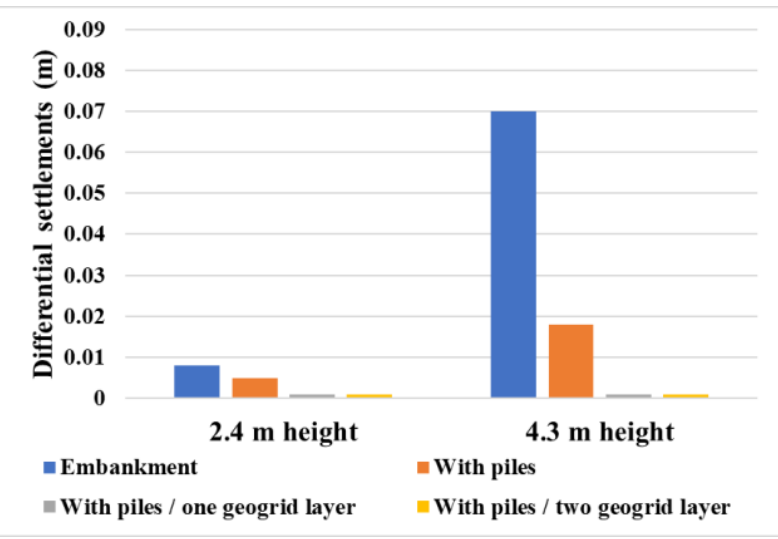

Figure 5. Differential settlements at the embankment surface

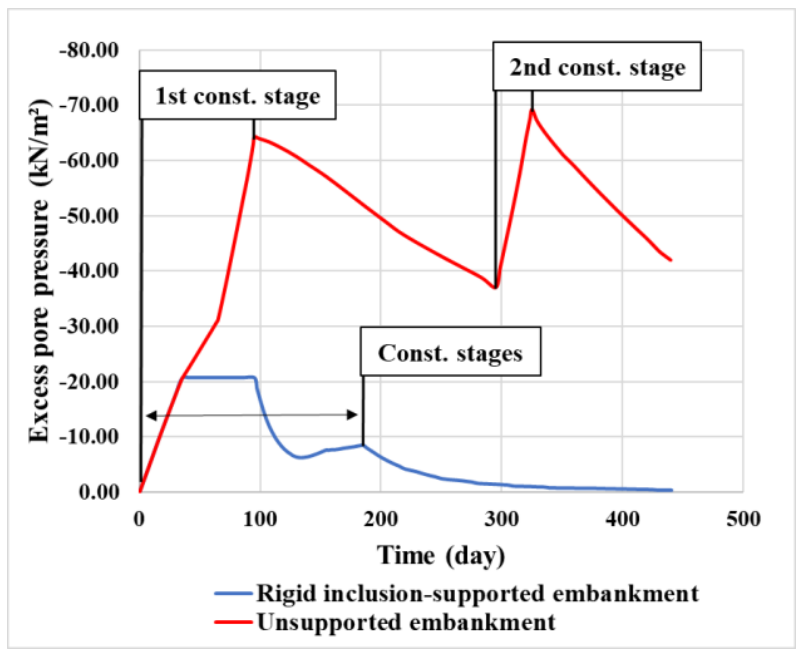

Figure 6. Excess pore pressure

\subsection{Creep (secondary settlement)}

Creep (secondary settlement) is one of the problems of soft soil. Because of their high compressibility, these soils suffer more from the secondary settlement than other soil types. Although the creep phenomenon is noticeable only after a long period, it is necessary to consider its effect. The use of rigid inclusions can ensure the stability of the embankment in the long term. After 25 years, the secondary 
settlement of the unsupported embankment reaches $0.54 \mathrm{~m}$, while it does not exceed $0.012 \mathrm{~m}$ for the supported embankment by rigid inclusions, as shown in Fig. 7 .

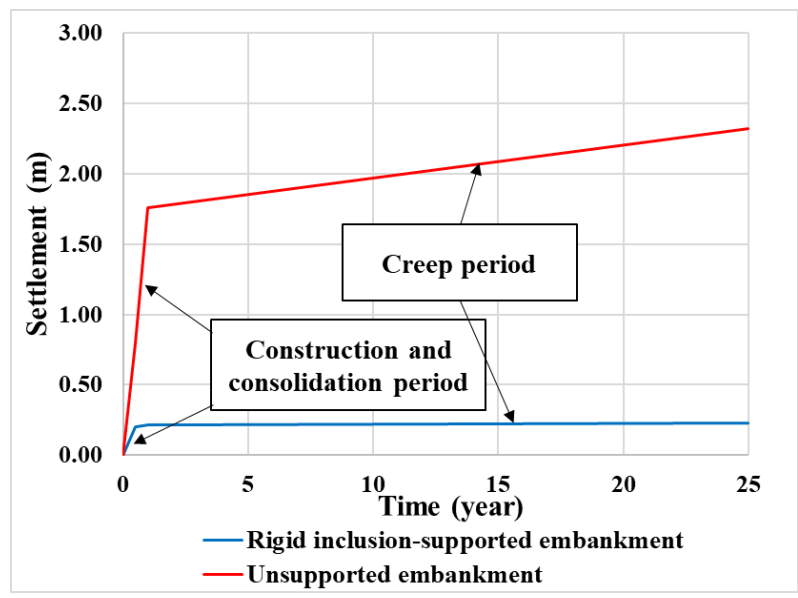

\section{Figure 7. Creep (secondary settlement)}

\subsection{Vertical and Shear stresses distribution}

The embankment settles more over the soft soil than over the piles due to the difference in stiffness. This movement causes the soil arch to form over the piles to carry the main load resulting from the weight of the embankment and the uniform surcharge load. This in turn results in a reduction in the settlement of the soft soil. Fig. 8 illustrates the soil arch in the embankment body. (Plaxis 2D program was used to clarify this phenomenon).

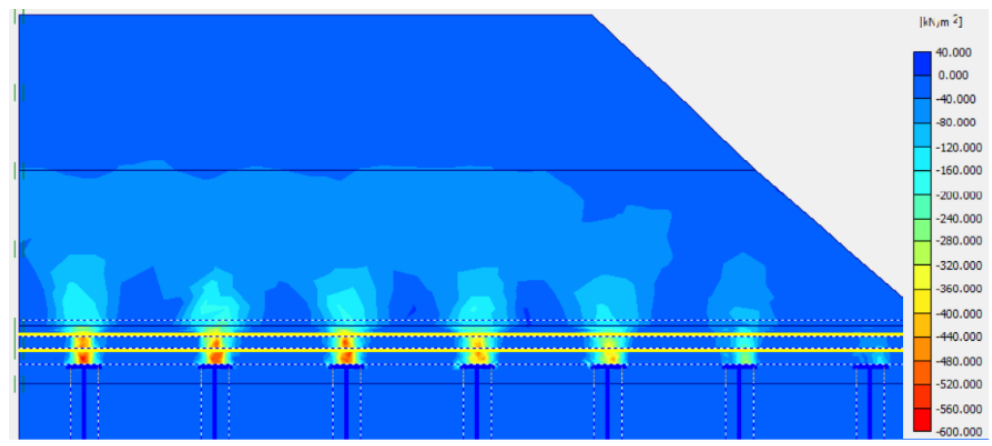

Figure 8. Soil arch in the embankment body 
The vertical stress in the midway between two piles in the embankment body increases to a certain depth and then decreases to a depth near the base of the embankment. The vertical stress then increases again due to the soil weight under the soil arch, where the depth of decrease in vertical stress represents the height of the soil arch. Fig.9 shows the distribution of vertical stress during the different stages of construction.

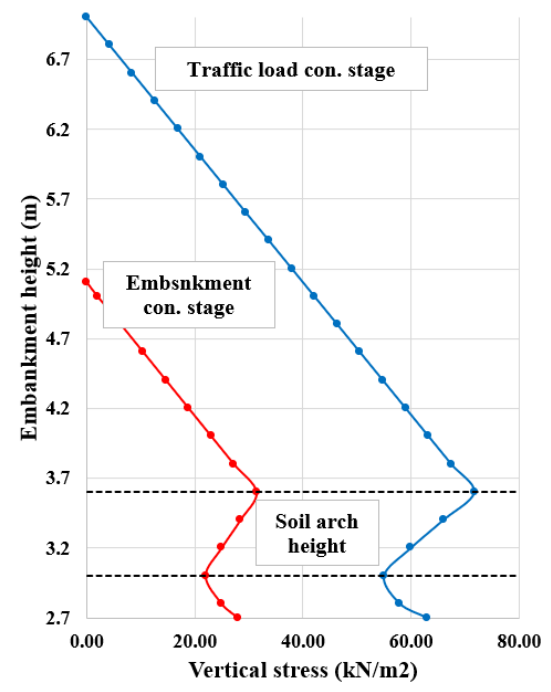

Figure 9. Vertical stress distribution

The shear stresses contribute to the determination of the shear planes which in turn represent the external and internal surfaces of the soil arch, Fig. 10 illustrates the shear stresses over the pile head. (Plaxis 2D program was used to clarify this phenomenon). 


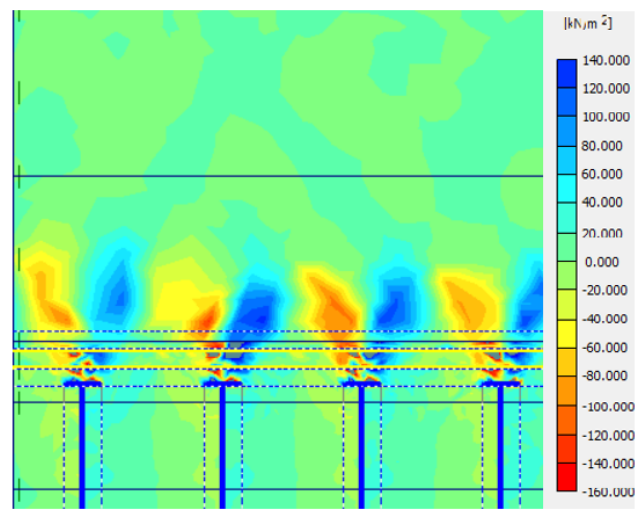

Figure 10. Shear stress distribution

\subsection{Soil-pile interaction}

Along the upper part of the soft soil and the working platform (if any), soil settlement is greater than the vertical displacement of the pile, which in turn leads to produce negative skin friction. Positive skin friction occurs when the vertical displacement of the rigid inclusion is greater than the soil settlement.

The settlements of the soft soil and the settlements along the pile axis are equal at three neutral lines, which can be characterized as follows:

1. The first neutral line: this line is located inside the embankment body and represents the upper limit of the soil arch.

2. The second neutral line: this line is located inside the soft soil layers that are penetrated by the pile, the loads acting on the pile are composed of the load at the pile head and the load from negative skin friction. These loads increase up to the second neutral line and then begin to decrease due to resisting forces, which include the positive skin friction force and tip resistance.

3. The third neutral line: this line is located within the gravel layer, Fig. 7a shows the settlement distribution at the end of the consolidation period in a unit cell and Fig. 7b shows the axial force profile in the pile. 


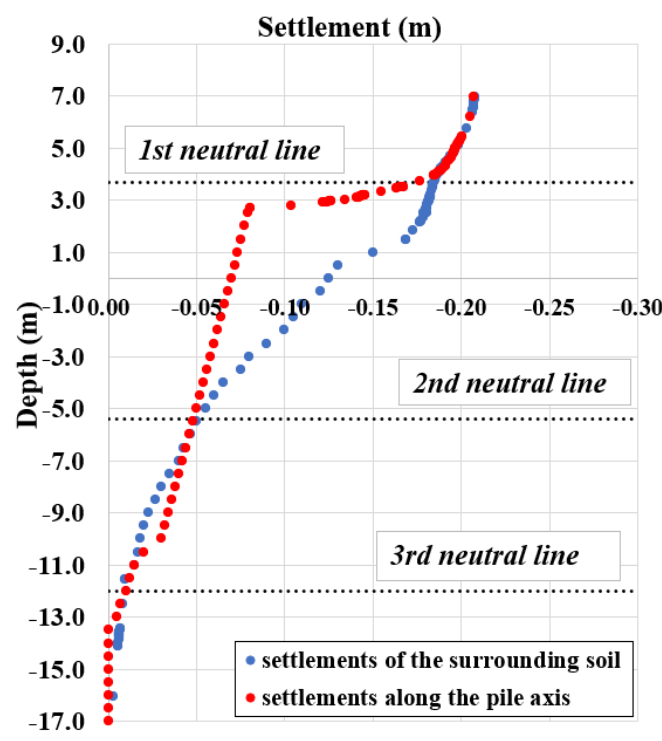

(a)

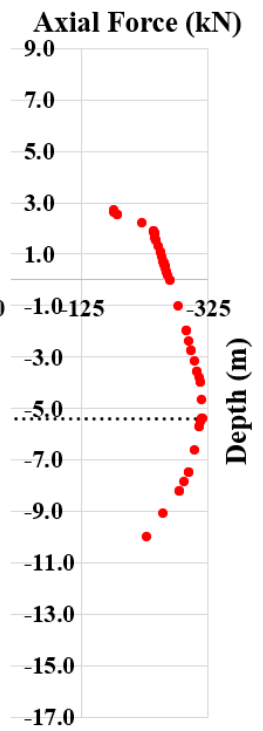

(b)

Figure 11. The settlements (a) and the axial force in the unit cell (b)

\subsection{Load efficiency}

Mathematically, the load efficiency can be expressed by:

$$
E=\frac{\sigma_{p}}{(\gamma H+q)}
$$

where $\sigma_{p}$ is the vertical stress applied on the pile head.

Fig. 12 shows the effect of using geogrid layers on the load efficiency at different heights of the embankment. For this case study, the load efficiency is constant in the two height cases studied when this technology is used without geogrid layers. The use of one geogrid layer increases the load efficiency by about $42 \%$ and the use of two geogrid layers increases the load efficiency by $44 \%$, the geogrid layers contribute to improving the load transfer to the piles. 


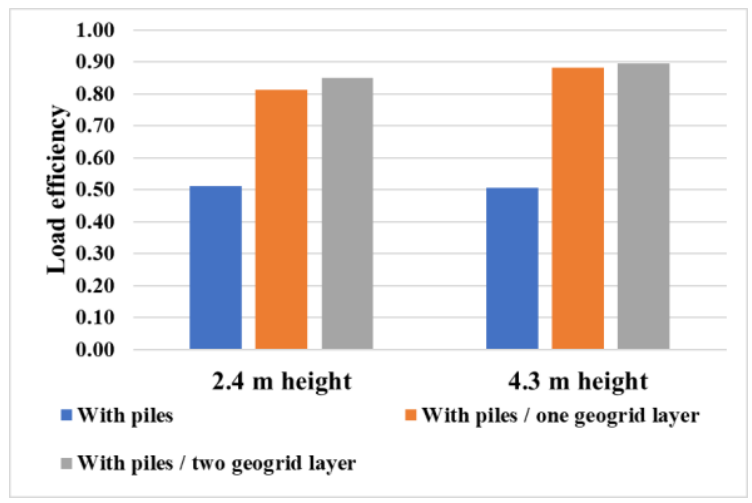

Figure 12. Load efficiency of the pile.

\subsection{Comparison of design methods}

\subsubsection{Comparison using the load efficiency}

The load efficiency for each design method is calculated for the present case study. The results are compared with those predicted by the 3D analysis. Out of the six design methods, Guido's method yields a slightly higher value but close to the prediction of the numerical analysis, and Tuan A. Pham's method yields a relatively lower value but can be considered close to the prediction of the numerical analysis. Terzaghi, Hewlett and Randolph, Abusharar, and BS8006 methods give low values for the load efficiency as shown in Fig. 13.

\subsubsection{Comparison using the geogrid tension}

The methods of Guido and Tuan A. Pham and relatively Abusharar yield values of geogrid tension in good agreement with the results of the 3D analysis. The methods of Terzaghi, Hewlett and Randolph, and BS8006 tend to overpredict the geogrid tension with different proportions as shown in Fig. 14. 


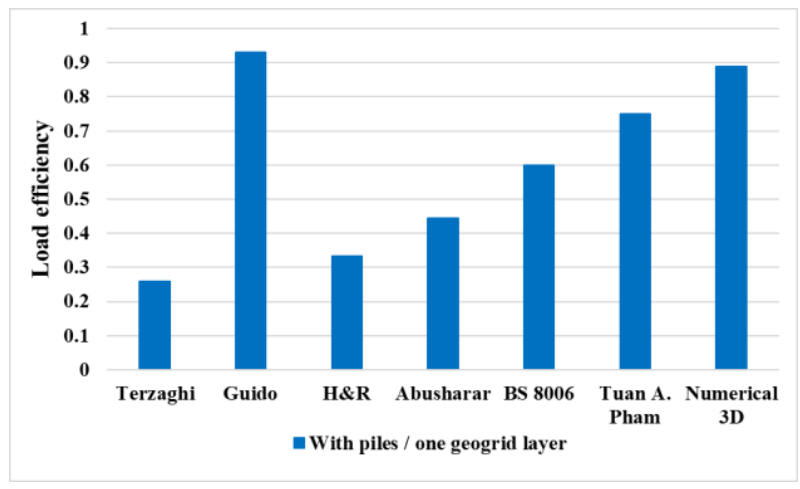

Figure 13. Pile load efficiency with different methods.

Guido's method depends on the clear pile spacing, and embankment height in the calculations, while Tuan A. Pham's method takes into account the properties of embankment fill, soft soil support, stiffness and deflections of geosynthetic layer, friction between soil and geosynthetic layer, embankment height, and clear pile spacing. On this basis, the Tuan A. Pham method can be relied upon as it is the most comprehensive not only with the Guido method but also with other analytical methods. The only disadvantage of the Tuan A. Pham method is the complexity of the calculations.

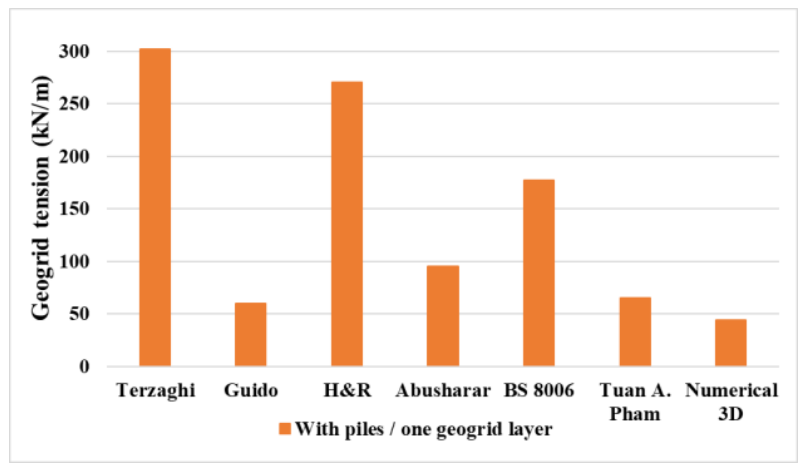

Figure 14. Geogrid tension with different methods.

\section{Conclusions}

In this paper, a numerical analysis of a validated model of a rigid inclusion-supported embankment has been performed using Plaxis 3D program. The results are as follows: 
1. The main part of the load is directly transferred to the pile heads (caps) through soil arches. This phenomenon can be explained by the difference in stiffness between piles and surrounding soil. The shear stresses contribute to form these arches in the embankment body.

2. Three neutral lines can be found in this system where the settlements of the soft soils and the displacement of the piles are the same. the first one is in the embankment body and represents the upper limit of the soil arch. the second one is in the soft soil layers and the third one is in the firm layer where the piles rest.

3. The use of rigid inclusions helps to reduce the maximum and differential settlements at the embankment surface to allowable limits compared to an unsupported embankment.

4. The insertion of the geogrid layers within the load transfer platform increases the load efficiency by $42 \%$ in the case of one layer and by $44 \%$ in the case of two layers.

5. The use of rigid inclusions reduces the excess pore pressure dissipation period which is considered suitable for time-bound construction projects.

6. Rigid inclusions reduce the secondary settlement to be imperceptible compared to $0.54 \mathrm{~m}$ settlement of the unsupported embankment after 25 years of operation, this phenomenon is considered one of the soft soils' problems.

7. Six analytical design methods are used in this paper and compared with the results of numerical analysis. These methods give different results because they consider only some of all the parameters in this complex system and use different calculation methods. The methods of Guido and Tuan A. Pham provide values of load efficiency that are close to the prediction of numerical analysis. The methods of Terzaghi, Hewlett and Randolph, Abusharar, and BS8006 provide low values of load efficiency and tend to overestimate the geogrid tension.

8. Tuan A. Pham design method is showing the closest results to the 3D FEM calculations

\section{References}

[1] IREX. Recommendations for the design, construction and control of rigid inclusion ground improvements. Project National ASIRI. Presses des Ponts, (2012).

[2] S.J.M. van Eekelen, A. Bezuijen, Model experiments on geosynthetic reinforced piled embankments, 3D test series, EuroFuge Conference, Delft University,

Netherlands,

(2012). 
doi: https://doi.org/10.4233/unid:1e82ac26-c5db-4247-9619e482e8916390.

[3] J. Han, A. Gabr, Numerical Analysis of Geosynthetic-Reinforced and PileSupported Earth Platforms over Soft Soil, Journal of Geotechnical and Geoenviromental engineering 128 (1) (2002) pp. 44-53. doi: $\quad$ https://doi.org/10.1061/(ASCE) 1090$0241(2002) 128: 1(44)$.

[4] B. Chevalier, P. Villard, G. Combe, Investigation of Load-Transfer Mechanisms in Geotechnical Earth Structures with Thin Fill Platforms Reinforced by Rigid Inclusions, International Journal of Geomechanic 11 (3) (2011) pp. 239-250. doi: https://doi.org/0.1061/(ASCE) GM.1943-5622.0000083.

[5] S.W. Abusharar, J.J. Zheng et al. A simplified method for analysis of a piled embankment reinforced with geosynthetics, Geotextiles and Geomembranes 27 (2009)

pp. 39-52. doi: https://doi.org/0.1016/j.geotexmem.2008.05.002.

[6] T. A. Pham, Analysis of geosynthetic-reinforced pile-supported embankment with soil-structure interaction models, Computers and Geotechnics 121 (1) (2020) pp. 1-17.

doi: https://doi.org/10.1016/j.compgeo.2020.103438.

[7] S. Fischer, T. Szatmari, Investigation of the geogrid-granular soil combination layer with laboratory multi-level shear box test, Eurogeo 6 conference, Ljubljana, Slovenia, 2016, pp. 439-449.

[8] T. Szatmari, S. Fischer, A. Trombitas, Investigation of geogrid-granular soil combination layer, Geosyntetika conference, Zilina, Slovakia, 2017.

[9] Y. Zhuang, K. Y. Wang, H. L. Liu, A simplified model to analyze the reinforced piled embankments, Geotextiles and Geomembranes 42 (2) (2014) pp. 154-165.

doi: https://doi.org/10.1016/j.geotexmem.2014.01.002.

[10] S.J.M van Eekelen, A.Bezuijen et al., Model experiments on piled embankments. Part I, Geotextiles and Geomembranes 32 (2012) pp. 69-81. doi: https://doi.org/0.1016/j.geotexmem.2011.11.002. 
[11] R. Girout, M. Blanc et al., Geosynthetic reinforcement of pile-supported embankments, Geosynthetics International 25 (1) (2018) pp. 37-49. doi: https://doi.org/10.1680/jgein.17.00032.

[12] K. Terzaghi, Theoretical Soil Mechanics, John Wiley \& Sons, Inc, New York, USA, 1943, $526 \mathrm{p}$.

[13] V. A. Guido, J. D. Kneuppel, M. A. Sweeney, Plate loading tests on geogrid reinforced earth slabs. Geosynthetic Conference 87, New Orleans, 1987, pp. 216-225.

[14] W. J. Hewlett, M. F. Randolph, Analysis of piled embankments, Ground Engineering 22 (3) (1988) pp. 12-18.

[15] B. K. Low, S. K. Tang, V. Choa, Arching in piled embankments, Journal of Geotechnical Engineering 120 (11) (1994) pp. 1917-1938.

[16] H. G. Kempfert, C. Gobel et al., German recommendations for the reinforced embankments on pile-similar elements, 4th Asian Regional Conference on Geosynthetics, Shanghai, China, 2008, pp. 697-702. doi: https://doi.org/10.1007/978-3-540-69313-0_128.

[17] R. Alsirawan, Review of Geosynthetic-Reinforced Pile-Supported (GRPS) embankments - parametric study and design methods, Acta Technica $\begin{array}{llllll}\text { Jaurinensis } & 14 & \text { (1) } & \text { (2020) } & \text { 36-59. }\end{array}$ doi: https://doi.org/10.14513/actatechjaur.00566.

[18] P. Ariyarathne, D. S. Liyanapathirana, Review of existing design methods for geosynthetic-reinforced pile-supported embankments, Soils and Foundations 55 (1) (2015) pp. 17-34.

doi: https://doi.org/10.1016/j.sandf.2014.12.002.

[19] Code of Practice for Strengthened/reinforced Soils and Other Fills, BS8006$1: 2010$ (2010).

[20] Recommendations for Design and Analysis of Earth Structures using Geosynthetic Reinforcements, EBGEO:2010 (2010). 
[21] E. Ellis, R. Aslam, Arching in piled embankments. comparison of centrifuge tests and predictive methods, Part 1 of 2, Ground Engineering 42 (6) (2009) pp. 34-38.

[22] E. Ellis, R. Aslam, Arching in piled embankments. Comparison of centrifuge tests and predictive methods, Part 2 of 2, Ground Engineering 42 (6) (2009) pp. 28-31.

[23] S.J.M van Eekelen, A.Bezuijen, A.F.van To, Model experiments on piled embankments. Part II, Geotextiles and Geomembranes 32 (1) (2012) pp. 8294.

doi: https://doi.org/10.1016/j.geotexmem.2011.11.003.

[24] X. Cui, Y. Zhuang et al., An analytical method to calculate the settlement of reinforced piled embankment considering three dimensional deformed geogrid, European Journal of Environmental and Civil Engineering (2020) doi: https://doi.org/0.1080/19648189.2020.1810130.

[25] D. Russell, N. Pierpoint, An assessment of design methods for piled embankments, Ground Engineering 30 (11) (1997) pp. 39-44. URL https://trid.trb.org/view/476724.

[26] S.J.M.van Eekelen, A.Bezuijen, A.F van Tol, Analysis and modification of the British Standard BS8006 for the design of piled embankments, Geotextiles and Geomembranes $29 \quad$ (3) (2011) pp. 345-359. doi: https://doi.org/0.1016/j.geotexmem.2011.02.001.

[27] L. Briançon, B. Simon, Pile-supported embankment over soft soil for a highspeed line, Geosynthetics International 24 (3) (2017) pp. 293-305. doi: https://doi.org/10.1680/jgein.17.00002. 